\title{
Zero Tillage (ZT) Potato Cultivation
}

\author{
Archita Ojah', Dhiraj Bhattacharjee ${ }^{2}$ \\ Department of Agronomy, Assam Agricultural University, Jorhat-785 013, Assam, India.
}

Received: August 2021

Accepted: January 2022

\begin{abstract}
Background: Minimum input and Maximum output are the new emerging trends in agriculture. To cope up with the sharp rise in population and limiting farm land, as well as to increase farm income there is an immediate need to increase the present cropping intensity. Such can be achieved when the long duration rice fallows are proficiently brought under intensive cultivation. Zero tillage technology is done without land preparation after harvesting the paddy; hence the cost of cultivation is less than the normal potato cultivation which in turn helps the farmers to get a better income.

Methods: In Sonitpur and Barpeta district of Assam, zero tillage survey was incorporated recently; Potato can be grown in those rice fallows successfully. The zero-tillage practice would allow crop intensification and aid to additional farm income without much soil and environmental degradation as compared to any traditional practices. It's time that farmers are made aware of these conservation agricultural practices for the greater good.

Result: ZT-practice can benefit the farmers by cutting down the cost on labour and other expensive farm practices along with minimizing the associated risks of environmental degradation.
\end{abstract}

Key words: Cropping, Degradation, Fallows, Tillage.

\section{INTRODUCTION}

Crop intensification, minimum input use and maximum possible output is the new requirement in Agriculture today. Zero tillage potato cultivation is one such promising technology for cropping system intensification in the rainfed lowland areas where mono cropping has been practiced on a larger scale till date. In areas where long duration rice is being grown as the sole crop during Kharif whereas most of the land remains fallow during the subsequent Rabi season. There is a need to increase the cropping intensity to increase the yield as well as the economic return from the farm. Potato can be successfully grown using the ZT cultivation system just after Kharif rice. With the initiatives taken under international potato centre (CIP), zero tillage potato cultivation has been fabulously adopted in various regions of the states. The mono cropped areas have been turned into double and triple cropping through this system slowly but successfully. Farmers today can adopt the ZT potato cultivation practice as this system can give higher yield with limited labour and water use thus making the whole production system a lot more economic. Soil penetration resistance was increased by as much as $1000 \mathrm{kPa}$ with some systems. However, soil penetration resistance did not approach levels that are considered detrimental to root growth (1500 k Pa) (Holmstrom et al, 2006).

\section{MATERIALS AND METHODS}

In Rabi session of 2019-20 at the research farmer's field of Sonitpur and Barpeta Districts of Assam, zero tillage potato cultivation has recently been started and sowing of potato can be done in the wet soil by zero tillage on the day when the rice crop is harvested in the field. However, there should not be any standing water in the field (Sarangi et al 2018). For facilitating the early sowing of potato, the land should be drained two weeks before. Early sowing of Zero tillage potato helps in better growth under low temperature conditions which is essential for less disease-pest incidence and higher tuber yield.

The "No-till" potato is pressed into the wet soil surface manually and then covered with a thick layer of mulch material like straw, which is fairly stable and does not rot quickly. Rice straw can be successfully used for this purpose. Barley (Hordeum vulgare) straw mulch significantly increased potato yield in comparison to the till system. Marketable yield was the highest with no-till potato at 50 and $75 \mathrm{t} /$ ha compared to no-till potato at all tested surface straw rates. None of the treatments was harmful to potato plants compared to the till potato (Msheik et al 2019).

In the ridge and furrow system of planting, ridges are to be made at suitable distance with the help of a spade. Tubers are then to be planted in those ridges at about 4 to $4.5 \mathrm{~cm}$ deep. Seed tubers are first allowed to germinate and then large sized tubers are cut into pieces with at least two germinating eyes. The tubers should be sown at 10 to $15 \mathrm{~cm}$ hill to hill and 30 to $35 \mathrm{~cm}$ row to row distance. The tubers must be covered with dry compost/farmyard manure and then NPK fertilizer $(10: 26: 26)$ is applied. Over the compost a thick layer $(20-30 \mathrm{~cm})$ of paddy straw is to be

*Corresponding author's E-mail: archita12ojah@gmail.com

${ }^{1}$ Department of Agronomy, Assam Agricultural University, Jorhat-785 013, Assam, India.

${ }^{2}$ Department of Horticulture, Assam Agricultural University, Jorhat-785 013, Assam, India. 
laid to cover the entire area. Since the tubers are formed inside the paddy-straw, proper covering of the tuber is the most important practice in this technology.

Certified potato seeds from verified authentic sources must be collected for growing in the field for obtaining higher yield. Potato must be propagated from pure and healthy seed tubers which are uniform in shape and size. Tubers can be sown either as a whole or cut into smaller pieces of 40-50 g in weight (Sarangi et al 2018). Potato tubers having sprouts of about $1 \mathrm{~cm}$ long in length at sowing are suitable for planting. Kufri Pukhraj is one of the recommended varieties that can be used for the purpose of zero tillage system.

Nutrients are essential for Potato cultivation. Application of FYM @ 3-5 tonne/ha and 10:26:26 kg N: $\mathrm{P}_{2} \mathrm{O}_{5}: \mathrm{K}_{2} \mathrm{O}$ per hectare is recommended for Zero tillage in Potato cultivation. 19:19:19 $\mathrm{kg} \mathrm{N}: \mathrm{P}_{2} \mathrm{O}_{5}: \mathrm{K}_{2} \mathrm{O}$ is also applied in Potato cultivation as soluble compounds in two doses $1^{\text {st }}$ spray to be given at 30 days after sowing while $2^{\text {nd }}$ spray at 45 days after sowing (Sarangi et al, 2018). In an experiment, $2 \%$ Urea at 30 and 50 at DAP of potato along with $0.1 \%$ Boron at 30 DAP as foliar application is the best foliar nutrient management option for potato grown under zero tillage and mulching in coastal saline soils of West Bengal, India. Comprehensive character and yield of Favorita seed potato tubers was the best and up to 1677.50 $\mathrm{kg} / 667 \mathrm{~m}^{2}$ respectively when the seed tubers were covered with rice straw and plastic film and the ratio of $N, P$ and $K$ fertilizer was 1:1:2. (Hong et al 2010).

\section{RESULTS AND DISCUSSION}

In zero tillage potato production systems, paddy straw is most commonly used mulching agent for reducing the moisture loss from the soil. At most 3-4 Irrigations are required in Potato crop, especially at 2 weeks after sowing, 5 weeks after sowing and tuber formation. The effect of mulches and irrigation scheduling on the growth and yield of ZT potato under rain fed low land rice ecosystem. Thick Layer of Mulching is required in zero tillage cultivation as potato needs to be kept in the dark to avoid the formation of chlorophyll, which renders the tubers green, bitter and toxic. (FAO, 2008). There was $37 \%$ reduction in irrigation water requirement of potato crop due to zero tillage cultivation (32.8 ha/cm) compared to conventional ridge sowing practices (52.1 ha/cm) (Sarangi et al 2018).

Among the different irrigation schedules single irrigation at 40 DAP gave maximum fresh tuber yield (8.62 t/ha) followed by splash irrigation ( $7.14 \mathrm{t} / \mathrm{ha}$ ) at 15 days interval. Single irrigation recorded the higher total dry matter production $\left(221.84 \mathrm{~g} / \mathrm{m}^{2}\right)$ and no. of tubers per hill (4.7) at harvest. Among the mulches water hyacinth recorded the highest tuber yield (9.64 t/ha) followed by paddy straw mulch ( $8.36 \mathrm{t} / \mathrm{ha})$, which might be attributed to higher plant height $(45.1 \mathrm{~cm})$, more number of haulms per hill (and tuber dry matter production $\left(141.6 \mathrm{~g} / \mathrm{m}^{2}\right.$ ) (Chettri et al 2018).
Tubers harvested from zero tillage have less moisture content compared to conventional ones as they are not in contact with soil directly and thus have better and longer keeping quality than the conventional ones. Compared with the routine film mulching, the yield of potato with the straw covering and zero-tillage cultivation was higher about $2.9 \%$, but the net income was lower about $16 \%$. The straw covering and zero-tillage cultivation technique of potato should be modified to spread and application after reducing the cost. (Meng 2012). Tuber yield harvested may vary from 7.5 to 26.9 tonne/ha (Sarangi et al 2018). The results showed that the yield under the zero tillage cultivation technique increases by $224.9 \mathrm{~kg} / 667 \mathrm{~m}^{2}$ compared with that under the traditional ridge cultivation model and its increase range is up to $16.2 \%$ and the fractional harvest can help big potatoes go on the market early, which can greatly raise its net income (2681.50 Yuan/667 $\mathrm{m}^{2}$ ) (Hong et al 2009). When potato is subjected to rice straw, rice husk and compost, highest stem and root dry matter were found from rice straw $\left(69.56 \mathrm{~kg} \mathrm{ha}^{-1}\right)$ and compost $\left(138.92 \mathrm{~kg} \mathrm{ha}^{-1}\right)$, respectively. Rice husk produced numerically highest leaf dry matter (372.74 $\left.\mathrm{kg} \mathrm{ha}^{-1}\right)$ and significantly lowest root dry matter $\left(87.92 \mathrm{~kg} \mathrm{ha}^{-1}\right)$, which ultimately produced highest tuber yield (13.99 $\left.\mathrm{t} \mathrm{ha}^{-1}\right)$ followed by rice straw (11.08 $\left.\mathrm{t} \mathrm{ha}^{-1}\right)$ (Ali et al., 2019).

\section{CONCLUSION}

Zero tillage potato tubers are harvested early and thus it can be easily adopted in rice based cropping systems. When pulse crop like green gram is added tip the cropping sequence along with zero tillage potato it helps in fixation of atmospheric nitrogen in soil and increase the soil-health and cropping intensity from mono-cropping (100\%) to triple cropping $(300 \%)$. Zero tillage will increase the profitability of the farmers and also increase the cropping intensity in this part of the country.

\section{REFERENCES}

Ali, M.A., Shahadat, M.K. and Rashid, M.H. (2019). Performance of zero tillage potato cultivation with different mulch materials in the South-Western Saline Area of Bangladesh. MDPI Proceedings. 36, 29; doi:10.3390/proceeding2019 036029.

Chettri, P. and Goswami, S.B. (2018). Effect of crop and non crop mulch management under varying moisture regimes on the growth and yield of zero tillage potato in rain-fed low land rice eco system. International Journal of Current Microbiology and Applied Science. 7(09): 2334-2339.

Holmstrom, D., Arsenault, W., Ivany, J., Sanderson, J.B. and Campbell, A.J. (2006). Effect of pre-plant tillage systems for potatoes in Prince Edward Island, Canada, on soil properties, weed control and potato yield. Journal of Soil and Water Conservation. 61(6): 370-380.

Hong, T., et al. (2009). The zero tillage cultivation technique for early spring potato and its economic benefit. Guizhou Agricultural Sciences. 6: 61-62. 
Hong, T., Ling, Z., JiaLi, W and ZiLin, C. (2010). Effect of mulch pattern and fertilizer combination on no-tillage cultivation of virus-free potato. Guizhou Agricultural Sciences. 8: 53-55.

Msheik, A., Haidar, M. and Jaafar, H. (2019). Strawponic for no-till potato production. American Journal of Plant Sciences. 10: 2159-2169. https://doi.org/10.4236/ajps.2019. 1012152.
Meng, G. (2012). Study on the straw covering and zero-tillage cultivation technique of potato. Shucheng Agricultural Technology Extension Center. 60-61+66.

Sarangi, S., Maji, B., Mahanta, K.K., Digar, S. (2018). Zero tillage potato cultivation-an innovative technology for coastal saline soils, Researchgate/326677803. 